\title{
PENGATURAN BISNIS PINJAMAN SECARA ONLINE ATAU FINTECH MENURUT HUKUM POSITIF DI INDONESIA
}

\author{
ARI RAHMAD HAKIM BF ${ }^{1)}$, I GUSTI AGUNG WISUDAWAN ${ }^{2)}$,YUDI SETIAWAN ${ }^{3)}$ \\ Fakultas Hukum Universitas Mataram \\ e-mail agung.wisudawan@gmail.com
}

\begin{abstract}
ABSTRAK
Pinjaman kredit secara online atau disebut dengan istilah Fintech yang sekarang berkembang di masyarakat Indonesia dan dianggap sebagai solusi mendapatkan pinjaman yang tanpa anggunan atau collateral untuk keperluan konsumtif. Berkembangnya Fintech ini tentu diperlukan pengawasan oleh pihak Otoritas Jasa Keuangan (OJK). Penelitian ini merupakan penelitian normatif dengan pendekatan perundangundangan, pendekatan konseptual dan pendekatan kasus. Penelitian ini juga menggunakan bahan hukum primer, skunder dan bahan hukum tersier. Adapun Tehnik pengumpulan bahan hukum yang dipergunakan dalam penelitian ini adalah studi dokumentasi bahan hokum, kemudian dianalisis secara deskriftif kualitatif.

Hasil penelitian menunjukan bahwa : 1). Pengaturan bisnis pinjaman kredit secara online atau fintech menurut hukum positif di Indonesia diatur oleh Peraturan Bank Indonesia, No 18/40/PBI/2016 dan No 19/12/PBI/2017, Peraturan Anggota Dewan Gubernur No 19/14/PADG/2017 dan No 19/15/PADG/2017. 2), Bentuk pengawasan yang dilakukan oleh pihak Otoritas Jasa Keuangan (OJK) terhadap bisnis pinjaman kredit secara online yaitu sistem pengawasan yang terintegrasi dan terkoordinasi antar struktur hukum seperti Polisi, BI. OJK, dan Satgas Waspada Investasi
\end{abstract}

Kata kunci: Pinjaman, kredit, pintech

\section{ABSTRACT}

Online credit lending or referred to as "Fintech" is now developing in Indonesian society and is considered as a solution to get loans without collateral for consumptive purposes. The development of Fintech certainly requires supervision by the Financial Services Authority (OJK). This research is a normative research with a statutory approach, conceptual approach, and case approach. This study also uses primary, secondary, and tertiary legal materials. The technique of collecting legal materials used in this research is the study of legal documentation, then analyzed in a qualitative descriptive manner.

The results show that: 1). Online credit loan or fintech business arrangements according to positive law in Indonesia are regulated by Bank Indonesia Regulation, No 18/40 / PBI / 2016 and No 19/12 / PBI / 2017, Member of the Board of Governors Regulation No. 19/14 / PADG / 2017 and No 19/15 / PADG / 2017. 2), the form of supervision carried out by the Financial Services Authority (OJK) of the online credit business is an integrated and coordinated supervision system between legal structures such as the Police, BI. OJK, and Investment Alert Task Force

Keywords: Loans, credit, fintech,

\section{PENDAHULUAN}

Teknologi komunikasi yang paling canggih saat ini adalah internet yang telah dikenal oleh seluruh masyarakat dunia tidak terkecuali Indonesia sejak tahun 2000-an. Perkembangan internet pasa saat ini dimanfaatkan oleh kalangan pebisnis untuk mendukung perdagangan yang mereka lakukan tidak hanya perdagangan dalam skala nasional tetapi juga skala internasional.

Bisnis yang terkenal pada saat ini yang melibatkan media internet adalah Pinjaman Kredit Secara Online atau disebut dengan istilah Fintech. Bisnis pinjaman secara online ini umumnya digemari oleh masyarakat Indonesia dan dianggap sebagai solusi mendapatkan pinjaman yang tanpa anggunan atau collateral untuk keperluan konsumtif. Memang benar argumentasi yang menyatakan bahwa bisnis ini sangat 
membantu masyarakat memperoleh kredit tetapi masyarakat belum memahami bisnis ini secara langsung terutama tentang akibat hukumnya.

Permasalahan yang muncul berkaitan dengan Pinjaman Kredit Secara Online atau disebut dengan istilah Fintech ini adalah terkait dengan Konsep hukumnya, pengaturannya, hubungan hukum para pihak, mekanisme pinjaman online dan keabsahan perjanjian pinajaman kredit secara online ini menurut hukum perjanjian dan hukum positif di Indonesia dan perizinan dan pengawasan bisnis ini oleh Otoritas Jasa Keuangan (OJK).

Selain itu pula masyarakat juga harus memahami tentang berbagai resiko yang muncul dari bisnis pinjaman kredit secara online ini. Sebaba dibalik keuntungan memperoleh pinjaman secara online ini tanpa anggunan ternyata bentuk penagihan yang dilakukan oleh perusahaan pengelola aplikasi fintech ini berupa pengancaman seperti rentenir serta terdapat beberapa perusahaan fintech yang tidak terdaftar di OJK, tentu ini akan sangat berbahaya sebab perusahaan fintech yang tidak terdaftar dapat dikategorikan sebagai perusahaan yang illegal dan pengancaman seperti praktik rentenir atau lintah darat adalah perbuatan melawan hukum dan terindikasi merupakan tindak pidana

\section{Perumusan Masalah}

Berdasarkan latar belakang sebagaimana diuraikan di atas, maka pokok permasalahan yang akan menjadi kajian dari penelitian ini dapat dirumuskan sebagai berikut:

1. Bagaimana pengaturan bisnis pinjaman kredit secara online atau fintech menurut hukum positif di Indonesia?

2. Bagaimana bentuk pengawasan yang dilakukan oleh pihak Otoritas Jasa Keuangan (OJK) terhadap bisnis pinjaman kredit secara online atau fintech?

\section{Tujuan dan Manfaat Penelitian}

Tujuan dari penelitian ini adalah untuk mengetahui pengaturan bisnis pinjaman kredit secara online atau fintech menurut hukum positif di Indonesia dan bentuk pengawasan yang dilakukan oleh pihak Otoritas Jasa Keuangan (OJK) terhadap bisnis pinjaman kredit secara online atau fintech. Hasil penelitian diharapkan dapat dimanfaatkan mengembangkan konsep-konsep hukum dalam Lembaga Keuangan terkait dengan Pengaturan Bisnis Fintech berdasarkan hukum positif di Indonesia dan secara praktis diharapkan dapat memberikan hasil yang sangat berguna bagi mahasiswa, praktisi hukum dan konsultan hukum serta otoritas (Bapepam dan OJK) dan praktisi lembaga keuangan

\section{METODE PENELITIAN}

Penelitian ini merupakan penelitian normatif yaitu penelitian yang mengkaji dan menganalisis tentang peraturan perundang-undangan maupun peraturan lain yang ada hubungannya dengan permasalahan di atas. Dalam melakukan penelitian normatif ini menggunakan peraturan perundang-undangan, teori hukum, pendapat hukum dari para ahli hukum terutama yang berkaitan dengan Bisnis Fintech. Adapun metode pendekatan yang digunakan dalam penelitian ini adalah Pendekatan Perundang-undangan (Statute Approach) yaitu pendekatan yang dilakukan dengan melihat semua peraturan perundang-undangan yang erat kaitannya dengan permasalahan yang akan diteliti. Hal ini dilakukan karena peraturan perundanganundangan merupakan titik fokus dari penelitian ini, Pendekatan Konseptual (Conceptual Aprroach) yaitu pendekatan yang merujuk dari pandangan-pandangan dan doktrin-doktrin di dalam ilmu hukum. Dengan mempelajari pandangan-pandangan dan doktrin-doktrin tersebut dihrapkan dapat menemukan ide-ide baru yang eksploratif mengenai pengertian-pengertian hukum, asas-asas hukum dan konsep-konsep dalam hukum, dan Pendekatan Kasus (Case Approach) yaitu pendekatan yang dilakukan dengan cara melakukan telaah terhadap kasus-kasus yang berkaitan dengan isu yang dihadapi.

Jenis dan sumber bahan hukum yang digunakan dalam penelitian ini adalah sebagai berikut : Bahan Hukum Primer yaitu bahan hukum yang berupa peraturan perundang-undangan yang berlaku serta ada kaitannya dengan permasalhan yang akan dibahas yaituPeraturan Bank Indonesia No 18/40/PBI/2016 Tentang Penyelenggaraan Pemrosesan Transaksi Pembayaran, Peraturan Bank Indonesia No 19/12/PBI/2017 Tentang Penyelenggaraan Teknologi Finansial,Peraturan Anggota Dewan Gubernur No 19/14/PADG/2017 Tentang Ruang Uji Coba Terbatas (Regulatory Sandbox ) Teknologi Finansial, Peraturan Anggota Dewan Gubernur No 19/15/PADG/2017 Tentang Tata Cara Pendaftaran Penyampaian Informasi dan Pemantauan Penyelenggaraan Teknologi Fainansial, Bahan Hukum Sekunder yaitu bahan hukum yang 
menjelaskan bahan hukum primer, yakni berupa rancangan perundang-undangan, hasil penelitian, bukubuku teks, seminar, diskusi dan berita internet, dan Bahan Hukum Tersier yaitu bahan hukum yang memberikan informasi tentang bahan hukum primer dan sekunder antara lain kamus hukum dan ensiklopedia yang dapat membantu memahami dan menganalisis masalah penelitian.

Teknik pengumpulan data menggunakan studi dokumentasi atau bahan pustaka yaitu dengan cara mengumpulkan bahan hukum yang dilakukan dengan jalan membaca dan mengkaji berbagai literaturliteratur dan bahan-bahan lainnya guna menemukan jawaban atau solusi terhadap masalah yang diteliti, Bahan Hukum yang telah terkumpul dalam penelitian ini kemudian dianalisis dengan mengunakan metode analisis kualitatif adalah analisis data yang diperoleh dari penelitian kepustakaan kemudian menguraikannya bermula dari hal-hal yang bersifat umum kepada hal-hal yang bersifat khusus.

\section{HASIL DAN PEMBAHASAN}

\section{Pengaturan Bisnis Pinjaman Kredit Secara Online atau Fintech Menurut Hukum Positif di Indonesia}

Munculnya Fintech ( Financial Technology) di tengah-tengah masyarakat tentu akan memunculkan unit-unit usaha baru sebab mudahnya dalam mengakses keuangan sehingga mengurangi pengangguran dan dapat meningkatkan taraf hidup masyarakat. Dengan adanya Fintech ( Financial Technology) ini juga akan merangsang angka perkembangan bitcoin, bitcoin merupakan aset digital yang dikembangkan pada tahun 2009 oleh seseorang dengan nama samaran Satoshi Nakamoto. Aset digital ini seperti halnya emas, namun hanya tersedia di dunia digital.

Adapun pengaturan dari bisnis Fintech ( Financial Technology) di Indonesia yaitu :

1. Peraturan Bank Indonesia No 18/40/PBI/2016 Tentang Penyelenggaraan Pemrosesan Transaksi Pembayaran.

2. Peraturan Bank Indonesia No 19/12/PBI/2017 Tentang Penyelenggaraan Teknologi Finansial.

3. Peraturan Anggota Dewan Gubernur No 19/14/PADG/2017 Tentang Ruang Uji Coba Terbatas (Regulatory Sandbox) Teknologi Finansial.

4. Peraturan Anggota Dewan Gubernur No 19/15/PADG/2017 Tentang Tata Cara Pendaftaran Penyampaian Informasi dan Pemantauan Penyelenggaraan Teknologi Fainansial.

Sebelumnya BI juga telah mengeluarkan SEBI Nomor 16/12/DPAU tanggal 22 Juli 2014 perihal Penyelenggaraan Layanan Keuangan Digital dalam rangka Keuangan Inklusif Melalui Agen Layangan Keuangan Digital Individu. SE tersebut memuat beberapa hal pokok, yaitu pengaturan mengenai perluasan bank penyelenggara LKD (Layanan Keuangan Digital), yaitu penerapan self registration, bulk registration, pelaksanaan uji coba bagi penerbit uang elektronik, serta kenaikan batas maksimum uang elektronik terdaftar (registered). Peningkatan kemudahan tersebut bertujuan untuk memperluas akses masyarakat terhadap layanan keuangan dan kenyamanan bertransaksi, serta mendukung program penyaluran bantuan sosial yang dilakukan Pemerintah.

Peraturan ini memang sangat diperlukan dalam rangka mengatur bisnis financial technology (fintech) di Indonesia terutama yang berkaitan dengan sisi instrumen, penyelenggara, mekanisme, maupun infrastruktur penyelenggaraan pemrosesan transaksi pembayaran yang tujuannya agar tercipta sistem pembayaran yang lancar, aman, efisien, dan andal, tanpa mengabaikan prinsip kehati-hatian (Prudential Principle), kepentingan nasional Indonesia dan perlindungan konsumen terutama yang berkaitan dengan penegakan hakhak konsumen yang dalam beberapa kasus dilanggar oleh pihak perusahaan technology (fintech) terutama technology (fintech) yang abal-abal.

Adapun berbagai substansi yang diatur di dalam Peraturan Bank Indonesia No 18/40/PBI/2016 Tentang Penyelenggaraan Pemrosesan Transaksi Pembayaran meliputi : a).Penyelenggara dalam pemrosesan transaksi pembayaran, b). Perizinan dan persetujuan dalam penyelenggaraan pemrosesan transaksi pembayaran, c). Kewajiban dalam penyelenggaraan pemrosesan transaksi pembayaran, d). Laporan, e). Peralihan izin penyelenggara jasa sistem pembayaran, f). Pengawasan, larangan, serta sanksi.

Dalam peraturan ini juga diatur tentang Penyelenggara asa Sistem Pembayaran terdiri atas: a). Prinsipal, b).Penyelenggara Switching, c).Penerbit, d). Acquirer e).Penyelenggara Payment Gateway f). Penyelenggara Kliring, g).Penyelenggara Penyelesaian Akhir, h).Penyelenggara Transfer Dana, i). Penyelenggara Dompet Elektronik,j).Penyelenggara Jasa Sistem Pembayaran lainnya yang ditetapkan oleh Bank Indonesia. 
Adapun Prinsip dasar izin atau persetujuan dalam penyelenggaraan pemrosesan transaksi pembayaran adalah sebagai berikut:

a. Pihak yang bertindak sebagai Penyelenggara Jasa Sistem Pembayaran wajib terlebih dahulu memperoleh izin dari Bank Indonesia.

b. Pihak yang telah memperoleh izin sebagai Penyelenggara Jasa Sistem Pembayaran dan akan melakukan pengembangan kegiatan jasa sistem pembayaran, pengembangan produk dan aktivitas jasa sistem pembayaran, dan/atau kerja sama dengan pihak lain, wajib terlebih dahulu memperoleh persetujuan dari Bank Indonesia.

Pihak yang mengajukan izin untuk menjadi Prinsipal, Penyelenggara Switching, Penyelenggara Kliring, dan/atau Penyelenggara Penyelesaian Akhir harus berbentuk perseroan terbatas yang paling sedikit $80 \%$ (delapan puluh persen) sahamnya dimiliki oleh warga negara Indonesia dan/atau badan hukum Indonesia.

Peraturan selanjutnya yang mengatur tentang keberadaan financial technology (fintech) yaitu Peraturan Anggota Dewan Gubernur Nomor 19/14/PADG/2017 tentang Ruang Uji Coba Terbatas (Regulatory Sandbox) Teknologi Finansial. Adapun substansi peraturan ini adalah sebagai berikut Peraturan Anggota Dewan Gubernur Nomor 19/14/PADG/2017 tentang Ruang Uji Coba Terbatas (Regulatory Sandbox) Teknologi Finansial (PADG Regulatory Sandbox) diterbitkan sehubungan dengan telah diundangkannya Peraturan Bank Indonesia Nomor 19/12/PBI/2017 tentang Penyelenggaraan Teknologi Finansial pada tanggal 29 November 2017 (PBI Tekfin). PADG Regulatory Sandbox ini berisi pengaturan teknis atas materi ketentuan yang diatur dalam PBI Tekfin dalam rangka memperjelas dan memberikan pedoman dalam penyelenggaraan ruang uji coba terbatas (Regulatory Sandbox).

Pokok-pokok yang diatur di dalam Peraturan Anggota Dewan Gubernur Nomor 19/14/PADG/2017 tentang Ruang Uji Coba Terbatas (Regulatory Sandbox) Teknologi Finansial adalah : a). ruang lingkup penyelenggaraan Teknologi Finansial, b).tata cara penetapan uji coba dalam Regulatory Sandbox; c). proses uji coba dalam Regulatory Sandbox; d). hasil uji coba dalam Regulatory Sandbox; e). kewajiban izin sebagai Penyelenggara Jasa Sistem Pembayaran.

Selanjutnya Bank Indonesia menetapkan Penyelenggara Teknologi Finansial beserta produk, layanan, teknologi, dan/atau model bisnisnya untuk diuji coba dalam Regulatory Sandbox. Proses uji coba dalam Regulatory Sandbox bukan merupakan proses perizinan yang dilakukan oleh Bank Indonesia dan Penyelenggara Teknologi Finansial yang telah memperoleh penetapan harus menyampaikan usulan skenario uji coba produk, layanan, teknologi, dan/atau model bisnis kepada Bank Indonesia dalam jangka waktu paling lama 10 (sepuluh) hari kerja sejak tanggal penetapan. Angka waktu uji coba dalam Regulatory Sandbox ditetapkan paling lama 6 (enam) bulan sejak tanggal penetapan Bank Indonesia atas skenario uji coba produk, layanan, teknologi, dan/atau model bisnis dan dalam hal diperlukan, jangka waktu sebagaimana dimaksud pada ayat (1) dapat diperpanjang 1 (satu) kali untuk waktu paling lama 6 (enam) bulan.

Selama pelaksanaan uji coba dalam Regulatory Sandbox, Penyelenggara Teknologi Finansial memiliki kewajiban sebagai berikut:

a. memastikan diterapkannya prinsip perlindungan konsumen serta manajemen risiko dan kehati-hatian yang memadai;

b. menyampaikan laporan pelaksanaan uji coba, baik secara reguler maupun insidentil sesuai dengan permintaan Bank Indonesia; dan

c. tetap menaati ketentuan peraturan perundang-undangan.

Bank Indonesia melakukan pendampingan dan review selama pelaksanaan uji coba dalam Regulatory Sandbox sebagai dasar untuk menetapkan status hasil uji coba Penyelenggara Teknologi Finansial. Kemudian nantinya Bank Indonesia menetapkan jangka waktu tertentu bagi Penyelenggara Teknologi Finansial untuk melakukan uji coba dalam Regulatory Sandbox. Setelah jangka waktu berakhir, Bank Indonesia menetapkan status hasil uji coba Penyelenggara Teknologi Finansial berupa: a). berhasil;b). tidak berhasil; atau c). status lain yang ditetapkan Bank Indonesia.

Setelah adanya Peraturan Anggota Dewan Gubernur Nomor 19/14/PADG/2017 tentang Ruang Uji Coba Terbatas (Regulatory Sandbox) Teknologi Finansial, seharusnya OJK (Otoritas Jasa Keuangan) segera mengeluarkan sebuah regulasi yang sama agar memiliki kewenangan untuk dapat melakukan ujicoba terhadap perusahaan Fintech yang ada di Indonesia.

Dari sisi lingkup pengawasan, kedua lembaga tersebut memiliki perbedaan. BI berwenang melakukan uji coba pada perusahaan fintech dengan jenis sistem pembayaran elektronik (e-payment), seperti Go-Pay. Sedangkan, OJK berhak melakukan penilaian pada fintech jasa keuangan seperti 
crowdfunding (pembiayaan), peer to peer lending (layanan pinjam-meminjam uang berbasis teknologi). https://www.hukumonline diakses 16 Nopember 2019 Jam 17.00 wita)

Selanjutnya Untuk mengikuti program regulatory sandbox, perusahaan fintech harus mendaftarkan diri kepada regulator terlebih dahulu. Selanjutnya, perusahaan mengikuti beberapa tahap penilaian. Misalnya, penilaian kondisi internal seperti profil manajemen dan reputasi pengurus, kebaruan dan manfaat produk, pendanaan serta konsultan hukum. Selain itu, regulator menilai sisi eksternal perusahaan, seperti persaingan usaha dan perlindungan konsumen, informasi, edukasi, dan penyelesaian sengketa konsumen.Melalui proses regulatory sandbox ini, regulator dapat mengetahui kondisi manajemen dan produk yang ditawarkan perusahaan fintech. Setelah melakukan berbagai tahapan penilaian, regulator berwenang memberi pernyataan kelayakan dari perusahaan tersebut. Berbagai tahapan dalam proses uji coba Regulatory Sandbox adalah sebagai berikut

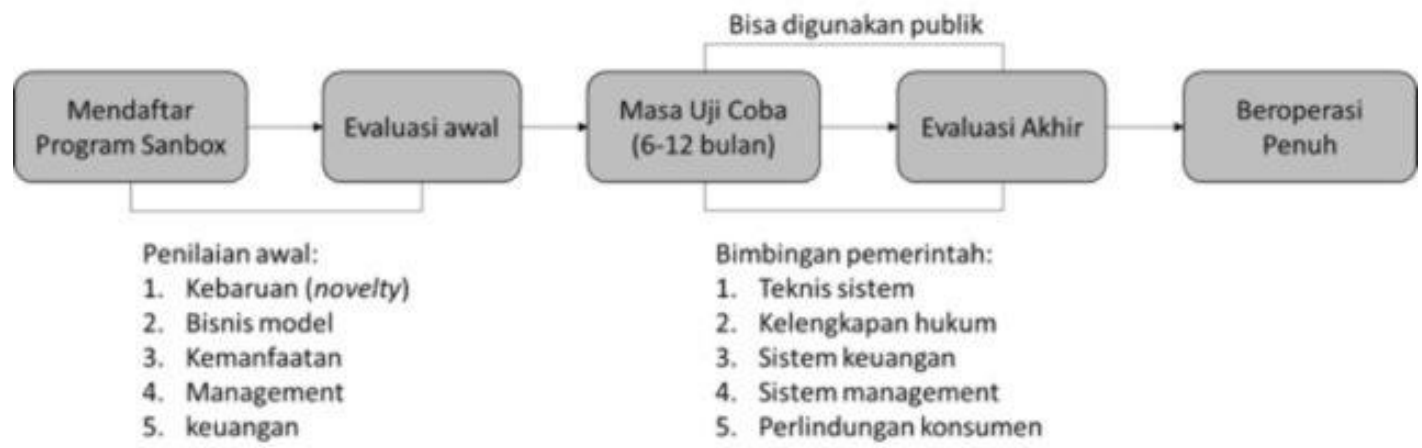

Regulasi terakhir yang digunakan untuk mengatur kegiatan Fintech di Indonesia adalah Peraturan Anggota Dewan Gubernur Nomor 19/15/PADG/2017 tentang Tata Cara Pendaftaran, Penyampaian Informasi, dan Pemantauan Penyelenggara Teknologi Finansial yang substansinya berkaitan dengan hal-hal sebagai berikut adapun dasar pertimbangkan dikeluarkannya peraturan ini adalah sehubungan dengan telah diundangkannya Peraturan Bank Indonesia Nomor 19/12/PBI/2017 tentang Penyelenggaraan Teknologi Finansial pada tanggal 29 November 2017 (PBI Tekfin). PADG ini berisi pengaturan teknis atas materi ketentuan yang diatur dalam PBI Tekfin dalam rangka memperjelas dan memberikan pedoman pendaftaran bagi Penyelenggara Teknologi Finansial.

Pokok-pokok yang diatur di dalam regulasi ini adalah :

a. Pendaftaran; antara lain mencakup tata cara, pemrosesan, publikasi pendaftaran, dan penghapusan pendaftaran.

b. Prinsip Manajemen Risiko dan Kehati-hatian.

c. Pemantauan; antara lain mengatur pemantauan oleh BI terhadap TekFin terdaftar, serta tata cara penyampaian informasi.

d. Ketentuan lain-lain; mengatur terkait dengan korespondensi dengan Bank Indonesia.

Prinsip manajemen resiko dan kehati-hatian masih menjadi perhatian utama dari Bank Indonesia dalam hal Tata Cara Pendaftaran, Penyampaian Informasi, dan Pemantauan Penyelenggara Teknologi Finansial di Indonesia, ini tentunya harus diapreasi oleh seluruh pihak agar tercipta kondisi yang aman dan nyaman dalam menggunakan layanan keuangan melalui Fintech ini.

Penyelenggara TekFin yang memenuhi kriteria sesuai PBI TekFin wajib melakukan pendaftaran, kecuali bagi Penyelenggara Teknologi Finansial yang berada di bawah kewenangan otoritas lain dan Penyelenggara Jasa Sistem Pembayaran yang telah memperoleh izin dari BI. Namun demikian, Penyelenggara Jasa Sistem Pembayaran dimaksud harus tetap menyampaikan infromasi kepada Bank Indonesia mengenai produk, layanan, teknologi, dan/atau model bisnis baru yang memenuhi kriteria

Teknologi Finansial. Penyelenggara Teknologi Finansial harus merupakan badan usaha, khusus bagi Penyelenggara Jasa Sistem Pembayaran harus berbentuk badan hukum sesuai ketentuan yang mengaturnya.

Penyelenggara Teknologi Finansial menyampaikan permohonan pendaftaran kepada Bank Indonesia secara tertulis disertai dengan dokumen pendaftaran secara daring (online).

Penyelenggara Teknologi Finansial yang telah terdaftar akan dipublikasikan pada laman resmi Bank Indonesia dan dapat dihapus apabila:

a. produk, layanan, teknologi, dan/atau model bisnis sudah tidak digunakan oleh Penyelenggara Teknologi Finansial;

b. Penyelenggara Teknologi Finansial telah memperoleh izin dari Bank Indonesia atau otoritas yang berwenang; 
c. Penyelenggara Teknologi Finansial dikenakan sanksi oleh Bank Indonesia dan/atau otoritas yang berwenang;

d. Penyelenggara Teknologi Finansial terbukti melakukan tindak pidana atau dinyatakan pailit berdasarkan putusan pengadilan yang berkekuatan hukum tetap;

e. terdapat rekomendasi dan/atau permintaan tertulis dari otoritas berwenang;

f. permintaan tertulis dari Penyelenggara Teknologi Finansial; dan/atau

g. Penyelenggara Teknologi Finansial menyampaikan data dan/atau informasi yang tidak sesuai dengan kondisi sebenarnya.

Selanjutnya Penyelenggara Teknologi Finansial wajib menyampaikan data dan/atau informasi yang diminta oleh Bank Indonesia berupa: a).transaksi terkait penyelenggaraan Teknologi Finansial, yang disampaikan secara berkala, b). produk, layanan, teknologi dan/atau model bisnis;c). kondisi keuangan; d). kepengurusan dan kepemilikan; dan e). data dan/atau informasi lain.

Adapun data mengenai perkembangan bisnis financial technology (fintech) DI Indonesia Berdasarkan data dari World Bank Findex 2018, hingga tahun 2017 inklusi keuangan di Indonesia baru tercapai 49 persen dimana target pemerintah pada tahun 2019 harus mencapai 75 persen. Di sektor produk pinjaman, Otoritas Jasa Keuangan (OJK) menyatakan jumlah peminjam dana yang memanfaatkan jasa perusahaan tekfin terus bertambah. Hingga kuartal I 2018, jumlah peminjam di perusahaan tekfin berbasis P2P Lending mencapai 1,032 juta orang dengan nilai pinjaman tercatat mencapai $\mathrm{Rp} 4,7$ triliun (https://ekonomi.kompas.com/read/2018/06/22/). Hal ini menunjukkan bahwa masyarakat Indonesia sangat menggemari layanan keuangan melalui Fintech.

Selain peraturan di atas ada pula Salah satu aturan yang diterbitkan OJK adalah Peraturan Otoritas Jasa Keuangan (POJK) No.77/POJK.01/2016 tentang Layanan Pinjam Meminjam Uang Berbasis Teknologi Informasi, yang mewajibkan Penyelenggara/platform fintech lending untuk mengedepankan keterbukaan informasi terhadap calon pemberi pinjaman dan peminjamnya agar dapat menilai tingkat risiko peminjam dan menentukan tingkat bunga_(https://keuangan.kontan, diakses hari Sabtu, Tanggal 16 Nopember 2019 Jam 19.00 wita). Keterbukaan informasi memang sangat dibutuhkan dalam rangka melindungi konsumen dari kerugian yang disebabkan oleh kelalaian perusahaan Fintech dalam memberikan layanannya.

Hubungan hukum antara perusahaan Fintech dengan pihak nasabahnya atau konsumen adalah perjanjian pinjam meminjam atau perjanjian kredit yang telah diatur di dalam Pasal Pasal 1754 KUHPerdata yang menyebutkan bahwa "pinjam-meminjam adalah persetujuan dengan mana pohak yang satu memberikan kepada pihak yang lain sesuatu jumlah tentang barang-barang atau uang yang menghabiskan karena pemakaian, dengan syarat bahwa pihak yang belakangan ini akan mengembalikan dengan jumlah yang sama dari macam dan keadaan yang sama pula". Ketentuan Pasal 1754 KUHPerdata tersebut menunjukkan bahwa seseorang yang meminjamkan sejumlah uang atau barang tertentu kepada pihak lain, ia akan memberi kembali sejumlah uang yang sama sesuai dengan persetujuan yang disepakati. Hanya saja kesepakatan yang dilakukan oleh kedua belah pihak dapat melalui teknologi internet termasuk mengupload dokumen yang diperlukan, mengenai signaturenya atau tandatangan tanda telah terjadi kesepakatan bagi Fintech yang legal biasanya bertemu dengan nasabahnya, tetapi bagi Fintech abal-abal terkadang tanpa tanda tangan hanya persetujuan ya atau tidak saja di internet. Inilah sumber masalah sebenarnya karena para pihak tidak bertemu pada saat penandatangan hanya tertulis di pesan singkat sms atau internet "Pinjaman Anda Telah Disetujui". Sedangkan jika dikaitkan dengan dasar keterikatan secara kontraktual ada dua unsur yaitu adanya kehendak (wills) dan) pernyataan (verklaring) (Muhammad Syaifuddin, 2012 :13) Adanya unsur kehendak sudah ada sehingga apara pihak sepakat dalam membuat perjanjian, tetapi yang menjadi persoalan adalah unsur pernyataan yang diikuti dengan perbuatan penandatanganan tidak ada, karena kedua pihak tidak bertemu secara langsung.

Lebih lanjut Muhammad Syaifuddin (2012) menyatakan bahwa penentuan momentum terjadinya kesepakatan yang menimbulkan kontrak menemukan kendala, khususnya jika penawaran tersebut dan penerimaan dilakukan melalui korespondensi atau surat menyurat mempunyai implikasi yang penting yaitu : 1). Penentuan resiko, b). Kesempatan penarikan kembali penawaran, 3).Saat mulai dihitungnya jangka waktu kadaluarsa, 4). Menentukan terjadinya kontrak

Berkaitan dengan sahnya suatu kontrak apabila kedua belah pihak tidak bertemu tetapi menggunakan media termasuk teknologi internet, tentu kesepakatan yang akan terjadi ditentukan oleheori dalam hukum kontrak : (http://vitaorrin.blogspot.com/2013/11/) yaitu :

1. Teori Ucapan (Uitings Theorie). teori ini berpijak kepada salah satu prinsip hukum bahwa suatu kehendak baru memiliki arti apabila kehendak tersebut telah dinyatakan. Menurut teori ini, kata sepakat terjadi pada saat pihak yang menerima penawaran telah menulis surat jawaban yang menyatakan ia 
menerima surat pernyataan. Kelemahan teori ini yaitu tidak adanya kepastian hukum karena pihak yang memberikan tawaran tidak tahu persis kapan pihak yang menerima tawaran tersebut menyiapkan surat jawaban.

2. Teori Pengiriman (verzendings Theorie)

Menurut teori ini, kesepakatan terjadi apabila pihak yang menerima penawaran telah mengirimkan surat jawaban atas penawaran yang diajukan terhadap dirinya. Dikirimkannya surat maka berarti si pengirim kehilangan kekuasaan atas surat, selain itu saat pengiriman dapat ditentukan dengan tepat. Kelemahan teori ini yaitu kadang terjadi perjanjian yang telah lahir di luar pengetahuan orang yang melakukan penawaran tersebut, selain itu akan muncul persoalan jika si penerima menunda-nunda untuk mengirimkan jawaban.

3. Teori Penerimaan (Ontvangs Theorie)

Menurut teori ini, terjadi pada saat pihak yang menawarkan menerima langsung surat jawaban dari pihak yang menerima tawaran.

4. Teori Pengetahuan (Vernemings Theorie)

Teori ini berpendapat bahwa kesepakatan terjadi pada saat pihak yang melakukan penawaran mengetahui bahwa penawarannya telah diketahui oleh pihak yang menerima penawaran tersebut. Kelemahan teori ini antara lain memungkinkan terlambat lahirnya perjanjian karena menunda-nunda untuk membuka surat penawaran dan sukar untuk mengetahui secara pasti kapan penerima tawaran mengetahui isi surat penawaran. Oleh karena itu pemahaman para pihak terhadap hukum perjanjian atau hukum kontrak sangat diperlukan guna menghindari konslik dalam pelaksanaan perjanjian dikemudian hari.

\section{Bentuk Pengawasan Yang Dilakukan Oleh Pihak Otoritas Jasa Keuangan (OJK) Terhadap Bisnis Pinjaman Kredit Secara Online atau Fintech}

Dalam https://gandengtangan.co.id/blog/4, diakses 16 Nopember 2019 Jam 20.00 wita, disebutkan bahwa Perkembangan bisnis Fintech di Indonesia seperti yang telah mengalami peningkatan yang sangat signifikan. Perkembangan industri Fintech ini dipengaruhi oleh beberapa hal yaitu :

1. Menjangkau Berbagai Kalangan Pengguna, 2. Lebih Disukai Masyarakat karena Praktis dan Cepat,

3. Lebih Disukai Pengusaha Mikro

Daya tarik Fintech terletak pada kemudahan dalam pemenuhan persyaratan formal untuk memperoleh pinjaman, tidak seperti bank yang prosedur pencairan pinjaman memerlukan persyaratan yang ribet dan terkesan berbelit-belit. Dengan kata lain bahwa munculnya bisnis Fintech ini disebabkan adanya kebutuhan masyarakat yang meningkat terhadap daya hidup yang konsumtif dan kebutuhan atas pinjaman yang sederhana prosedur pengurusannya.

Perkembangan industri Fintech bukannya tanpa masalah, permasalahan baru muncul dikarenakan marak terjadi perbuatan melawan hukum dan perbuatan melanggar hukum yang dilakukan oleh oknum perusahaan Fintech yang merugikan konsumen pengguna layanannya. Kasus yang melibatkan perusahaan financial technology (fintech) makin banyak. Berdasarkan data Lembaga Bantuan Hukum (LBH) Jakarta, per Juni 2019 sudah ada 4.500 aduan tentang fintech lending. Sementara Satgas Waspada Investasi melaporkan ada sebanyak 683 entitas fintech peer to peer (P2P) lending ilegal yang telah dihentikan operasinya hingga Juli 2019. Pada tahun 2018 ada 404 fintech P2P lending yang dihentikan Satgas Waspada Investasi. Sehingga secara total sejak tahun 2018, Satgas Waspada Investigasi telah menghentikan 1.087 entitas fintech illegal https://keuangan.kontan.co.id/news/banyak-kasus-tingkat-kepercayaan-terhadap-fintech-menciut, diakses hari Sabtu, Tanggal 16 Nopember 2019 Jam 20.00 wita. https://keuangan.kontan.co.id/news/banyak-kasustingkat-kepercayaan-terhadap-fintech-menciut, diakses hari Sabtu, Tanggal 16 Nopember 2019 Jam 20.00 wita

Belakangan perkembangan fintech 'ternoda' dengan maraknya usaha-usaha fintech ilegal. Kondisinya bisa dibilang cukup memprihatinkan. Jenis-jenis pelanggaran hukum yang dilakukan fintech ilegal beragam, bisa berupa penagihan yang kasar hingga pelecehan seksual. Selain itu, tingginya bunga pinjaman hingga pencurian data pribadi melalui telepon seluler konsumen yang dilakukan perusahaan fintech menimbulkan dampak buruk terhadap konsumen. Tentu hal ini sangat meresahkan konsumen dan harus segera diatasi oleh OJK sebagai otoritas yang berwenang melakukan pengawasan dan penegakan hukum terhadap kasus-kasus Fintech yang meresahkan ini agar tidak mencoreng bisnis Fintech di masa yang akan datang.

Sekadar catatan, sampai Februari 2019 sudah ada 99 perusahaan fintech peer to peer lending yang terdaftar dan berizin OJK. Hingga pertengahan Maret 2019, Satgas Waspada Investasi telah menghentikan 
168 entitas fintech ilegal. Satgas juga mengklaim telah mendeteksi 803 entitas fintech ilegal. Satgas juga sudah meminta Kemkominfo untuk menutup fintech ilegal tersebut.

Sementara LBH Jakarta mencatat hingga Februari 2019 telah menerima sekitar 3 ribu pengaduan masyarakat terkait fintech ilegal. Selain LBH Jakarta, Asosiasi Fintech Pendanaan Bersama Indonesia (AFPI) menerima 426 pengaduan yang mengadukan 510 platform fintech P2P lending selama periode Januari - Maret 2019. Mayoritas laporan yang masuk adalah mengenai minimnya informasi yang diberikan oleh pelaku usaha terkait proses pinjam meminjam seperti besaran bunga, biaya administrasi. Kemudian terkait tingginya biaya bunga dan administrasi, proses penagihan yang di dalamnya terdapat tindak pidana fitnah, penipuan, pengancaman dan penyebaran data pribadi hingga sampai pada pelecehan seksual. Hal ini harus segera dilakukan penegakan hukum oleh pihak kepolisian bekerjasama dengan pihak Satgas Waspada Investasi dan OJK.

Keberadaan Satgas Waspada Investasi tentunya sangat penting dalam menertibkan investasi yang bermasalah dan merugikan investor atau konsumen.Satgas Waspada Investasi dibentuk melalui Surat Keputusan Ketua Bapepam dan LK Nomor: Kep-208/BL/2007 tanggal 20 Juni 2007 untuk masa kerja tahun 2007 yang diperbarui setiap tahunnya. Setelah beralihnya tugas dan fungsi Bapepam dan LK menjadi Otoritas Jasa Keuangan (OJK), Surat Keputusan Satgas Waspada Investasi tersebut diperbarui melalui

Keputusan Dewan Komisioner OJK Nomor: 01/KDK.04/2013 tanggal 26 Juni 2013(https://www.ojk.go.id/waspada-investasi/id/berita/Pages/OJK-Perkuat-Satgas-Waspada-Investasi.aspx, diakses pada hari Sabtu, Tanggal 16 Nopember 2019 Jam 21.00 wita

Nota Kesepakatan antar pimpinan institusi anggota Satgas Waspada Investasi disusun sebagai payung hukum Satgas untuk memperkokoh komitmen bersama antara Kementerian/Lembaga dalam pelaksanaan tugas pokok Satgas Waspada Investasi.

1. Revitalisasi pelaksanaan tugas Satgas Waspada Investasi antara lain meliputi :

2. Preventif

a. Koordinasi antara anggota Satgas Waspada Investasi dalam rangka meningkatkan edukasi dan pemahaman mengenai ruang lingkup transaksi keuangan yang berpotensi merugikan masyarakat

b. Sosialisasi kepada komponen masyarakat, penegak hukum, pemerintah daerah dan akademisi

c. Mengidentifikasikan dan mengevaluasi serta tindakan yang diperlukan terhadap tawaran-tawaran investasi melalui berbagai sarana pemasaran tidak terbatas kepada penyampaian melalui internet

d. Mengefektifkan sarana pengaduan Satgas Waspada Investasi

3. Kuratif

a. Kerjasama dalam penerbitan ijin keramaian/penyelenggaraan kegiatan penawaran investasi

b. Melakukan pembinaan berupa peringatan terhadap perusahaan yang melakukan penawaran investasi yang berpotensi merugikan masyarakat agar mendapatkan ijin dan beroperasi sesuai dengan ketentuan yang berlaku

4. Represif. Melakukan tindakan hukum terhadap pelanggaran ketentuan dan perundang-undangan.

Jadi hadirnya Satgas Waspada Investasi yang dibentuk oleh OJK ini adalah untuk memberikan perlindungan hukum bagi investor dan konsumen agar nyaman dalam berinvestasi. Perlindungan hukum merupakan segala upaya yang dilakukan seseorang atau sekelompok orang untuk mengamankan haknya dari orang lain yang akan melanggar hak tersebut. Hal yang terpenting dalam memberikan perlindungan hukum bagi konsumen adalah ketepatan dankecepatan dalam bertindak agar ekses negatif dari perbuatan melawan hukum dan melanggar hukum itu tidak meluas. Di sinilah diperlukan penggunaan teori sistem.

Pengawasan merupakan bentuk perlindungan hukum yang diberikan oleh pihak terkait dalam hal ini BI dan OJK dalam mewujudkan sistem layanan keuangan yang memberikan dampak positif bagi kemajuan ekonomi Indonesia. Pengawasan ini dilakukan untuk menilai suatu pekerjaan yang tengah berjalan apakah sudah sesuai dengan yang direncanakan atau tidak. Jika dikaitkan dengan bisnis Fintech bahwasannya BI dan OJK melakukan pengawsan dalam rangka melakukan penilaian apakah bisnis Fintech ini telah sesuai dengan apa yang diharapkan atau belum sesuai dengan harapan sehingga diperlukan tindakan korektif untuk memperbaikinya.

Dalam rangka melakukan pengawasan terhadap Fintech di Indonesia maka OJK mengeluarkan Peraturan OJK No. 13/POJK.02/2018 tentang Inovasi Keuangan Digital di sektor jasa keuangan sebagai ketentuan yang memayungi pengawasan dan pengaturan industri financial technology (fintech). Aturan ini dimaksudkan untuk memberikan perlindungan hukum bagi masyarakat pengguna layanan keuangan Fintech. 
Adapun pokok-pokok pengaturan Inovasi Keuangan Digital (IKD https://www.liputan6.com /bisnis/read/3633889/ojk) antara lain:

\section{Mekanisme Pencatatan dan Pendaftaran Fintech}

Setiap penyelenggara IKD baik perusahaan Startup maupun Lembaga Jasa Keuangan (LJK) akan melalui 3 tahap proses sebelum mengajukan permohonan perizinan:

a. Pencatatan kepada OJK untuk perusahaan Startup/non-LJK. Permohonan pencatatan secara otomatis termasuk permohonan pengujian regulatory sandbox. Sedangkan untuk LJK, permohonan sandbox diajukan kepada pengawas masing-masing bidang (Perbankan, Pasar Modal, IKNB).

b. Proses regulatory sandbox berjangka waktu paling lama satu tahun dan dapat diperpanjang selama 6 bulan bila diperlukan.

c. Pendaftaran/perizinan kepada OJK.

\section{Mekanisme Pemantauan dan Pengawasan Fintech}

OJK akan menetapkan Penyelenggara IKD yang wajib mengikuti proses regulatory sandbox. Hasil uji coba regulatory sandbox ditetapkan dengan status: a. Direkomendasikan. b. Perbaikan. c. Tidak direkomendasikan.

Penyelenggara IKD yang sudah menjalani regulatory sandbox dan berstatus direkomendasikan dapat mengajukan permohonan pendaftaran kepada OJK. Untuk pelaksanaan pemantauan dan pengawasan, penyelenggara IKD diwajibkan untuk melakukan pengawasan secara mandiri dengan menyusun laporan self assessment yang sedikitnya memuat aspek tata kelola dan mitigasi risiko.Penyelenggara IKD dilarang mencantumkan nama dan/atau logo OJK namun dapat mencantumkan nomor tanda tercatat/terdaftar.Dalam jangka menengah, OJK dapat menunjuk pihak lain (Asosiasi Penyelenggara IKD yang diakui oleh OJK) yang bertugas dalam pengawasan IKD.

\section{Pembentukan Ekosistem Fintech}

Untuk memelihara ekosistem keuangan, Lembaga Jasa Keuangan yang telah memperoleh izin atau terdaftar di OJK dilarang bekerja sama dengan Penyelenggara IKD yang belum tercatat di OJK atau terdaftar di otoritas lain yang berwenang guna memelihara ekosistem keuangan.

\section{Membangun Budaya Inovasi}

OJK menginisiasi pembentukan Pusat Inovasi Keuangan Digital (Fintech Center) dan ekosistem IKD yang bertujuan sebagai sarana komunikasi, koordinasi, dan kolaborasi antara otoritas terkait dan pelaku IKD serta wadah Inovasi dan Pengembangan IKD.

\section{Inklusi dan Literasi}

Penyelenggara IKD wajib melaksanakan kegiatan untuk meningkatkan literasi dan inklusi keuangan kepada masyarakat.

\section{Bisnis dan Perlindungan Data}

Penyelenggara IKD wajib menyediakan pusat pelayanan konsumen berbasis teknologi sebagai bentuk penerapan edukasi dan perlindungan konsumen beserta usahanya.

\section{Manajemen Risiko yang Efektif}

Penyelenggara IKD wajib menerapkan prinsip pemantauan secara mandiri, menginventarisasi risiko utama, menyusun laporan risk self assessment secara bulanan, dan memiliki perangkat yang dapat meningkatkan efisiensi dan kepatuhan atas proses pemantauan yang dilakukan oleh OJK.

\section{Kolaborasi}

Dengan dibentuknya Fintech Center, maka dapat membantu berjalannya proses Regulatory Sandbox sebagai langkah inkubasi model bisnis yang inklusif dan memenuhi prinsip kehati-hatian, serta meningkatkan sinergi antar industri, pemerintah, akademisi dan innovation hub lain.

\section{Perlindungan Konsumen}

Penyelenggara wajib menerapkan prinsip dasar perlindungan konsumen, yaitu (a) transparansi, (b) perlakuan yang adil, (c) keandalan, (d) kerahasiaan dan keamanan data/informasi konsumen, dan (e) penanganan pengaduan serta penyelesaian sengketa konsumen secara sederhana, cepat, dan biaya terjangkau.

\section{Transparansi}

Fintech wajib menerapkan prinsip pengawasan berbasis disiplin pasar, risiko dan teknologi terhadap inovasinya, antara lain harus memperhatikan transparansi produk dan layanan, pasar yang kompetitif dan inklusif, kesesuaian dengan kebutuhan konsumen, penanganan mekanisme keluhan yang segera, dan aspek keamanan dan kerahasiaan data konsumen dan transaksi. 


\section{Anti-Pencucian Uang dan Pendanaan Terorisme}

Perusahaan fintech juga wajib menerapkan program anti pencucian uang dan pencegahan pendanaan terorisme di sektor jasa keuangan terhadap konsumen sesuai ketentuan Peraturan OJK di bidang AML-CFT (Anti Money Laundering and Counter-Financing of Terrorism).

Terhadap pelanggaran yang dilakukan oleh Fintech tentu saja akan dilakukan penyelidikan dan penyidikan dengan sistem koordinasi dan terintegrasi antar struktur hukum seperti Polisi, BI. OJK, dan Satgas Waspada Investasi. Adapun sanksi yang dapat diekankan bagi Fintech bermasalah adalah Sanksi Pidana, Sanksi Perdata dan Sanksi Administratif. Selain itu tindakan pengawasan dan evaluasi dilakukan untuk menciptakan kemanfaatan hukum yang sesuai dengan teori utilitarianisme oleh Jeremy Bentham yang pada intinya menyatakan Hukum dapat memberikan jaminan kebahagiaan kepada individu-individu, barulah kepada orang banyak. "the greatest happiness of the greatest number" (kebahagiaan yang sebesar-besarnya dari sebanyak-banyaknya orang).

Kegiatan pengawasan ini juga dilakukan untuk melindungi kepentingan konsumen atau masyarakat pengguna layanan keuangan Fintech sebagaimana yang telah diatur di dalam Undang-undang No 8 Tahun 1999 Tentang Perlindungan Konsumen terutama dalam Pasal 4 yang menyatakan bahwa :

1. Hak atas kenyamanan, keamanan dan keselamatan dalam mengkonsumsi barang dan/atau jasa;

2. Hak untuk memilih barang dan/atau jasa serta mendapatkan barang dan/atau jasa tersebut sesuai dengan nilai tukar dan kondisi serta jaminan yang dijanjikan;

3. Hak atas informasi yang benar, jelas dan jujur mengenai kondisi dan jaminan barang dan/atau jasa;

4. Hak untuk didengar pendapat dan keluhannya atas barang dan/atau jasa yang digunakan;

5. Hak untuk mendapatkan advokasi, perlindungan dan upaya penyelesaian sengketa perlindungan konsumen secara patut;

6. Hak untuk mendapat pembinaan dan pendidikan konsumen;

7. Hak untuk diperlakukan atau dilayani secara benar dan jujur serta tidak diskriminatif;

8. Hak untuk mendapatkan kompensasi, ganti rugi/penggantian, apabila barang dan/atau jasa yang diterima tidak sesuai dengan perjanjian atau tidak sebagaimana mestinya;

9. Hak-hak yang diatur dalam ketentuan peraturan perundang-undangan lainnya.

Selanjutnya yang perlu menjadi catatan bersama bahwasannya pekembangan Fintech Ilegal di Indonesia tidak bisa juga diabaikan oleh karena itu diperlukan komitmen bersama untuk membersihkan itu semua. Apalagi ditambah dengan dugaan oknum bank yang menjual data nasabah sehingga data tersebut dapat dimiliki oleh perusahaan Fintech yang abal-abal untuk memperalat konsumen. Masukan juga kepada Fintech yang legal penerapan Prinsip Kehati-hatian dan Prinsip Mengenal Nasabah juga sangat penting untuk dilakukan dalam memberikan perlindungan bagi bisnis Fintech itu sendiri dari perlakukan konsumen yang tidak beritikad baik.

Dalam rangka melindungi konsumen perusahaan Fintech sebagai pelaku usaha harus melaksanakan kewajiban pelaku usaha yang telah diatur di dalam Pasal 7 Undang -undang No 8 Tahun 1999 Tentang Perlindungan Konsumen yang berbunyi :

1. bertikad baik dalam melakukan kegiatan usahanya.

2. Melakukan informasi yang benar, jelas, dan jujur mengenai kondisi dan jaminan barang atau jasa serta memberi penjelasan penggunaan, perbaika, dan pemeliharaan.

3. Memperlakukan atau melayani konsumen secara benar dan jujur serta tidak diskriminatif ; pelaku usaha dilarang membeda-bedakan konsumen dalam memberikan pelayanan; pelaku usaha dilarang membedabedakan mutu pelayanan kepada konsumen.

4. Menjamin mutu barang atau jasa yang diproduksi atau diperdagangkan berdasarkan ketentuan standar mutu barang atau jasa yang berlaku.

5. Memberi kesempatan kepada konsumen untuk menguji atau mencoba barang atau jasa tertentu serta memberi jaminan dan garansi .

6. Memberi kompensasi , ganti rugi atau penggantian atas kerugian akibat penggunaan, pemakaian, dan manfaat barang atau jasa yang diperdagangkan.

7. Memberi kompensasi ganti rugi atau penggantian apabila berang atau jasa yang diterima atau dimanfaatkan tidak sesuai dengan perjanjian. 


\section{SIMPULAN DAN SARAN}

\section{Simpulan}

1. Pengaturan bisnis pinjaman kredit secara online atau fintech menurut hukum positif di Indonesia yaitu Peraturan Bank Indonesia No 18/40/PBI/2016 Tentang Penyelenggaraan Pemrosesan Transaksi Pembayaran,Peraturan Bank Indonesia No 19/12/PBI/2017 Tentang Penyelenggaraan Teknologi Finansial,Peraturan Anggota Dewan Gubernur No 19/14/PADG/2017 Tentang Ruang Uji Coba Terbatas (Regulatory Sandbox ) Teknologi Finansial,Peraturan Anggota Dewan Gubernur No 19/15/PADG/2017 Tentang Tata Cara Pendaftaran Penyampaian Informasi dan Pemantauan Penyelenggaraan Teknologi Fainansial.

2. Bentuk pengawasan yang dilakukan oleh pihak Otoritas Jasa Keuangan (OJK) terhadap bisnis pinjaman kredit secara online atau fintech yaitu sistem pengawasan yang terintegrasi dan terkoordinasi antar struktur hukum seperti Polisi, BI. OJK, dan Satgas Waspada Investasi, selain itu juga kehadiran Satgas Waspada Investasi yang dibentuk berdasarkan Keputusan Dewan Komisioner OJK Nomor: 01/KDK.04/2013 tanggal 26 Juni 2013 sangat penting dan membantu untuk melakukan pengawasan yang intensif. Dari sisi regulasi OJK jg mengeluarkan aturan sebagai dasar untuk memayungi pengawasan dan pengaturan industri financial technology (fintech) di Indonesia yaitu Peraturan OJK No. 13/POJK.02/2018 tentang Inovasi Keuangan Digital di sektor jasa keuangan

\section{Saran}

1. Regulasi yang dikeluarkan oleh pemerintah dalam hal ini OJK juga harus memberikan berbagai kemudahan bagi bisnis Fintech agar dapat menumbuhkan inovasi yang kreatif artinya tidak perlu menjambah regulasi baru tetapi menguatkan regulasi yg sedah ada sebelumnya.

2. Perlu ada juga kejelasan regulasi terkait kolaborasi antara perbankan dengan lembaga keuangan lainnya, seperti perbankan, selain itu perlu juga ada insentif perpajakan, khususnya bagi Fintech yang bergerak di sektor pendanaan produktif yang bisa memberikan efek ekonomi lebih besar.

3. Memperkuat peran fintech, dan diperlukan kebijakan yang mampu menekan biaya akuisisi nasabah, meminimalisasi risiko penipuan, dan dapat konsumen beritikad baik.

4. Memperkuat peran Satgas Waspada Investasi dalam rangka mengawasi dan menindak Fintech yang abalabal dan meresahkan masyarakat dan diharapkan OJK tegas dalam memberikan sanksi hukum bagi Fintech yang bermasalah, sebab jika dibiarkan maka akan merusak kepercayaan publik terhadap bisnis Fintech ini.

\section{DAFTAR PUSTAKA}

Syah Mudakir Iskandar, 2108. Hukum Bisnis Online di Era Digital, Campustaka, Jakarta

Syaifuddin Muhammad, 2012. Hukum Kontrak (Memahami Kontrak Dalam Perspektif Filsafat, Teori, Dogmatik, dan Praktik Hukum Seri Pengayaan Hukum Perikatan), Mandar Maju,Bandung

http://jakartawebs.com/sejarah-dan-perkembangan-ecommerce-di-indonesia/ diakses pada hari Jumat, Tanggal 15 Nopember 2019 Jam 17.00 wita

https://www.cekindo.com/id/group1-id/perkembangan-teknologi-finansial-fintech-di-indonesia, diakses pada hari Jumat, Tanggal 15 Nopember 2019 Jam 17.00 wita

https://jojonomic.com/blog/fintech/ diakses pada hari Jumat, Tanggal 15 Nopember 2019 Jam 17.00 wita

https://smartlegal.id/smarticle/2019/01/08/mengenal-jenis-jenis-financial-technology/ diakses hari Jumat,

Tanggal 15 Nopember 2019 Jam 17.00 wita.

https://www.yuksinau.id/pengertian-globalisasi/ diakses hari Sabtu, Tanggal 16 Nopember 2019 Jam 10.00 wita.

https://www.hukumonline.com/berita/baca/lt5ad486b13effa/mengenal-mekanisme-regulatory-sandbox-padaindustri-fintech/ diakses hari Sabtu, Tanggal 16 Nopember 2019 Jam 17.00 wita

https://ekonomi.kompas.com/read/2018/06/22/060600726/apa-saja-syarat-untuk-mengajukan-pembiayaan-

fintech-?page=all diakses hari Sabtu, Tanggal 16 Nopember 2019 Jam 17.00 wita.

https://keuangan.kontan.co.id/news/banyak-kasus-tingkat-kepercayaan-terhadap-fintech-menciut, diakses hari Sabtu, Tanggal 16 Nopember 2019 Jam 19.00 wita

https://gandengtangan.co.id/blog/4-alasan-di-balik-pesatnya-pertumbuhan-industri-fintech-di-indonesia/ diakses hari Sabtu, Tanggal 16 Nopember 2019 Jam 20.00 wita 
https://keuangan.kontan.co.id/news/banyak-kasus-tingkat-kepercayaan-terhadap-fintech-menciut, diakses hari Sabtu, Tanggal 16 Nopember 2019 Jam 20.00 wita

https://www.hukumonline.com/berita/baca/lt5c9b2221dcb1c/perkembangan-dan-permasalahan-hukum-

fintech/ diakses pada hari Sabtu, Tanggal 16 Nopember 2019 Jam 21.00 wita

https://www.ojk.go.id/waspada-investasi/id/berita/Pages/OJK-Perkuat-Satgas-Waspada-Investasi.aspx,

diakses pada hari Sabtu, Tanggal 16 Nopember 2019 Jam 21.00 wita

http://taufiknurohman25.blogspot.com/2011/04/teori-sistem-david-easton.html, diakses pada hari Sabtu, Tanggal 16 Nopember 2019 Jam 21.00 wita

http://taufiknurohman25.blogspot.com/2011/04/teori-sistem-david-easton.html, diakses pada hari Sabtu, Tanggal 16 Nopember 2019 Jam 21.00 wita

https://www.seputarpengetahuan.co.id/2016/10/pengertian-pengawasan-menurut-para-ahli-lengkap.html

diakses pada hari Minggu Tanggal 17 Nopember 2019 Jam 08.00 wita

https://business-law.binus.ac.id/2016/06/30/utilitarianisme-dan-tujuan-perkembangan-hukum-multimedia-diindonesia/ diakses pada hari Minggu Tanggal 17 Nopember 2019 Jam 08.00 wita 